\title{
Almenpædagogik og fagdidaktik
}

En række af bidragene i dette nummer har udgangspunkt i DUN-konferencen 2010, hvor temaet var 'Den faglige vending i universitetspædagogikken: fra almen pædagogik til fagdidaktik'. Fagdidaktik handler om de aspekter ved planlægning og gennemførelse af undervisning, som relaterer sig til et specifikt fag, f.eks. matematikdidaktik eller engelskfagets didaktik, mens almenpædagogik inden for universitetspædagogik, tematiserer områder, som har en generel karakter for al universitetsundervisning, f.eks. motivation, frafald, generelle studiekompetencer, eksamens- og evalueringsformer. Uden fagligheder giver universitetspædagogikken ingen mening, men spørgsmålet er, om et fag vil give mening for de universitetsstuderende, hvis faget ikke kobles med grundige almenpædagogiske- og didaktiske overvejelser. At få et fag til at give mening for de studerende er en central underviseropgave. Det er, hvad de studerende oplever som meningsfuldt, der udgør rammen for deres læring, men at fă denne meningsfuldhed frem, ikke blot fra et underviserperspektiv, men også fra et studenterperspektiv, kræver relevant pædagogisk planlægning og udførelse. Man kan diskutere, hvordan almenpædagogik forholder sig til fagdidaktik. Findes der overhovedet almenpædagogik på universitetet, hvor fagligheden i den grad er i centrum? Svaret må være, at den almene pædagogik eksisterer, hvilket bl.a. kan erfares på kurser i universitetspædagogik, hvor der tydeligvis findes en lang række af temaer, som på tværs af fag, er relevante at forholde sig til for alle undervisere. Men derudover er det fagligheden, som er central, og det kræver både faglig og pædagogisk viden, hvis den skal udmøntes i en fagdidaktisk reflekteret og meningsfuld undervisning. Meningsfuldhed i undervisning kræver som minimum, at underviseren har faglig dybde og overblik over stoffet og de færdigheder og kompetencer som undervisningen skal resultere i. Hvis de studerende skal kunne finde vej i et fagligt landskab, er det nødvendigt, at en underviser kan understøtte de studerende $\mathrm{i}$ at begå sig i terrænet. Som beskrevet i artiklen af Nielsen, Caspersen og Dahl, så er det centrale at gå fra lærerprocesser til de studerendes læreprocesser.
I dette nummer af DUT tematiseres fagdidaktikken inden for sprog, idræt og naturvidenskab. På det almenpædagogiske felt tages der emner op som frafald, motivation, forståelse og studiekompetencer. Derudover er der to artikler, der adresserer specialeskrivning.

I dette nummer introduceres en ny ikke-reviewet kategori: 'Den pædagogisk-didaktiske værktøjskasse'. Ideen er, at gode ideer til gennemførelse af undervisning og vejledning kan præsenteres i kort og direkte form. Omfanget må maksimalt være 8000 tegn. incl. mellemrum.

Nedenfor følger korte referater af de enkelte artikler.

Lill Ingstad, Margrethe Smedegaard Mondahl, Jonas Rasmussen og Lisbet Pals Svendsen diskuterer i artiklen Sociale medier som læringsredskaber fagdidaktiske udfordringer i sprogundervisning med fokus på engelsk og med anvendelse af sociale medier som læringsredskaber. Artiklen argumenterer for, at sociale medier i særlig grad kan understøtte social og kollaborativ læring, fordi sociale medier danner ramme for læringsmiljøer, der støtter betydningsforhandling, samarbejde og vidensdeling. Fire undervisningsforløb fra Copenhagen Business School, der alle indeholder læring af såvel sproglige som kommunikative kompetencer, indgår som eksempelmateriale i artiklen.

Artiklen Det problembaserede undervisningsdesign. Fra ProPrak, til teori, til gruppearbejde af Mads Hovgaard begrunder og eksemplificerer det problembaserede undervisningsdesign Fra ProPrak, til teori til gruppearbejde, som forfatteren har anvendt $i$ et problembaseret og metodisk funderet undervisningsforløb på Syddansk Universitets idrætsuddannelse. Forskellige PBL-traditioner bliver også berørt. Indholdet, opbygningen og undervisningsformerne i forløbet tog afsæt i det problembaserede fagområdes teori og metoder, herunder 7-trinsmodellen. Kursusevalueringer viste, at undervisningsdesignet med ProPrak, teori og gruppearbejde har motiveret de studerende til konstant aktiv deltagelse samtidig med, at de har oplevet en høj grad af målopfyldelse. 
Artiklen Hvad skal ph.d.-studerende på naturvidenskab vide om undervisning? af Birgitte Lund Nielsen, Michael E. Caspersen og Bettina Dahl (Søndergaard) giver indblik i planlægning, gennemførelse og evaluering af et kursus $i$ undervisning og instruktion for ph.d.-studerende med assisterende undervisningsopgaver ved Det Naturvidenskabelige Fakultet på Aarhus Universitet. Forfatterne analyserer rammesætningen af kurset herunder forsøget på at give de deltagende novicer praktisk anvendelig kompetenceudvikling med udgangspunkt i Pedagogical Content Knowledge. Ud fra evalueringsresultater peges der frem mod videreudvikling af kurset, hvor deltagernes egne erfaringer vil skulle inddrages helt fra kursets start. Forfatterne foreslår perspektiverende, at kurset kan indgå som første trin $\mathrm{i}$ en progression fra informeret forbruger af didaktisk design til informeret producent af didaktisk design.

I artiklen Specialeskrivning på seks måneder. De nye specialeregler belyst ved erfaringer fra Institut på Statskundskab, Københavns Universitet redegør Henrik Jensen og Hanne Nexø Jensen for virkningerne af de nye regler for specialeskrivning, der betyder, at specialeskrivning skal foregå på 6 måneder. Undersøgelsen, som er gennemført på Institut for Statskundskab, Københavns Universitet, viser at langt flere studerende skriver deres speciale hurtigere end før, og der er heller ikke tegn på at kvaliteten er blevet ringere målt på karaktererne. Undersøgelsen viser også, at de studerende umiddelbart er tilfredse med de nye regler.

Tine Wirenfeldt Jensen og Søren Bengtsen redegør $i$ artiklen Fra løsninger til nye spørgsmål. Kandidatspecialet som forskningsfelt for, at meget af det hidtidige arbejde inden for det universitetspædagogiske forskningsfelt i Danmark har været motiveret af at løse presserende konkrete problemer, hvorfor universitetspædagogiske undersøgelser ofte sigter mod at komme med konkrete anvisninger til forbedringer af praksis. Forfatterne argumenterer for at udvide feltet til bidragstyper, som udfordrer og redefinerer feltet. I den forbindelse optegner de feltets allerede eksisterende tilgange til forskning i kandidatspecialet og udpeger, hvordan andre tilgange kunne være et supplement til feltet. De understreger her vigtigheden af, at specialet ikke blot ses som noget, man gør, eller noget, man ved noget om, men også som noget, man er eller bliver til.

Rie Troelsen samler og giver i artiklen Frafald på de videregående uddannelser - hvad ved vi om årsagerne? en oversigt over syv danske undersøgelser om årsagerne til frafald på de videregående uddannelser i tidsperioden 2000-2009. Omkring en tredjedel af de studerende på de videregående uddannelser afbryder deres studium - de fleste inden for det første år. Der er også henvisninger til internationale undersøgelser af frafald.Ved at sammenligne undersøgelserne bliver det tydeligere, om der er enslydende årsager til frafald på tværs af uddannelser, institutioner og fag, og på tværs af de metodiske valg, der er blevet gjort forud for indsamlingen af frafaldsårsagerne. Artiklen konkluderet, at der ikke kan peges på enkelte forhold, som kan forklare frafald. Artiklen giver også anbefalinger til fremtidige forskningsprojekter inden for feltet.

Ulla Thøgersen gør i sin artikel Samskabelse af engagement - om fastholdelse af de studerendes deltagelse $\mathbf{i}$ undervisning op med forestillingen om selvmotiverende studerende, som undervisningen kan tage udgangspunkt $i$. Hun foreslår en alternativ forståelse af motivation som samskabelse af engagement og giver en række positive eksempler på undervisning, der netop er baseret på samskabelse af engagement.

Lisbeth Lunde Frederiksens artikel Læselog som middel til dybdelæring handler om læseloggen som et pædagogisk redskab til at facilitere dybdegående læringsstrategi, kreativ forståelse, distribueret kognition og som udgangspunkt for en reel dialogisk aktiverende undervisning.

Argumentationen baseres på konstruktivistisk læringsteori $\mathrm{i}$ et sociokulturelt perspektiv og på Ramsdens teori om overfladestrategi og dybdestrategi i tilegnelse af fagligt stof. Forfatteren konkluderer, at der ligger nogle muligheder i periodevis at få de studerende til at arbejde med læselog for efterfølgende at bruge læseloggen som udgangspunkt for undervisningen. Arbejdet med læselog giver ikke blot flere studerende mulighed for dybdelæring og kreativ forståelse af et stof eller tema. Det giver også mulighed for at basere undervisningen på de studerendes indsats uden for undervisningen og etablere reel dialog med mulighed for større forståelse og perspektivering af stoffet.

I artiklen Forståelse i forskningsbaseret undervisning - især i relation til human- og samfundsvidenskab diskuterer Merete Wiberg, med udgangspunkt $i$ en sammenligning af to paradigmer inden for uddannelsestænkning, den angelsaksiske, eksemplificeret ved John Biggs og den kontinentale didaktiske, eksemplificeret ved Wolfgang Klafki, forskelle mellem beskrivelser af idealer for studerendes forståelse. Der argumenteres for, at der i forskningsbaseret forståelse må være en ontologisk dimension til stede med henblik på, at studerende kan se viden og vidensproduktion i relation til virkeligheds- og tilværelsestolkninger. Det pointeres, at didaktiktraditionen giver et væsentligt bidrag til dette perspektiv.

I kategorien den pædagogisk-didaktiske værktøjskasse giver Rikke von Müllen i artiklen At forberede forberedelsen et didaktisk redskab til gennemførelse af universitetsundervisning.

Vi modtager løbende artikelforslag. Retningslinjer, manuskriptvejledninger og beskrivelse af artikelkategorier findes på www.dun-net.dk. Send dit artikelforslag til dut@dun-net.dk. God skrive- og læselyst. 